\title{
The Influence of Product and Price toward Costumers' Satisfaction at Traditional Market in Sekayu
}

\author{
Sri Gustini ${ }^{1}$, Ika Rakhmalina ${ }^{1}$, Neti Erlina ${ }^{1}$, and Septaniar ${ }^{1}$ \\ \{ srigustini.mudrik@gmail.com, ika.rakhmalina@gmail.com,neti.erlina@gmail.com, \\ septaniar@gmail.com\} \\ ${ }^{1}$ Department of Economic Management, STIE Rahmaniyah Sekayu, Sekayu, Indonesia
}

\begin{abstract}
This research goal is to know the influence of product and price toward costumers' satisfaction at traditional market in Sekayu. In this research, sample was taken by using Maholtra with the total number of sample was 90 persons; those are the consumers of traditional market in Sekayu. Sampling technique is purposive sampling. Data was taken by using questionnaire which was been measured by Likert scale. This research used multiple linear regression analysis by helping of SPSS 17.00 version program. The research result showed that product variable $\left(\mathrm{X}_{1}\right)$ and price $\left(\mathrm{X}_{2}\right)$ pertially also have influence toward costumers' satisfaction at Sekayu traditional market.
\end{abstract}

Keywords: Product, price, consumers' satisfaction

\section{INTRODUCTION}

Traditional market is market which has an important role to advance the economic growth in Indonesia and has excellence compete scientifically. These Traditional markets presence are very helpful, not only for regional or central government but also all society who rely on their lives in trading activities, because in traditional markets there are many actors whom have important role and try to prosper their own lives such as sellers, buyers, porters and many others. All of them are the actors which have important roles in maintaining the excistence of traditional market in Indonesia.

According to Tjiptono [1], market is a place where the seller and buyer meet for goods and services offered to be sold and the transfer of ownership. Traditional markets are a meeting place for sellers and buyers and are characterized by direct sellers and buyers of products or services, the building usually consisting of kiosks or outlets, stalls and open bases opened by both the seller and the market manager.

According to Kotler \& Keller [2], product is everything offered to the market to get attention, bought, used and thise are able to satisfy the consumers' needs or willingness. And the product level consists of core benefit, basic product, expected product, enhanced product, and potential product. Traditional markets are one place where many sales of various products, where the business is now flooding traditional markets, both in quantity and type of food and beverages and entertainment offered, so that the entrepreneurs compete with each other in improving product quality and price varies. Because with good quality and affordable price is 
expected to provide a satisfaction to the consumer. With the achievement of needs, wants and expectations of the consumer then the producer's goal in increasing sales can be fulfilled.

According to Tjiptono [1], consumer satisfaction is a consumer condition which feel satisfy or dissatisfy after achieved his/her desire and expectation toward menu, price, faciluty and service offered. Consumer will feel satisfy if their desire and need have been fulfilled, and contrast consumers will feel dissatisfy if their desire and expectation haven't been fulfilled.

Traditional market in Sekayu is located at Talang Jawe Street Balai Agung Sekayu. This market is one of markets in Sekayu, it has strategic place to be choosen by buyers to buy things there. Beside its strategic location, it also has vary and products to be offered depend on Sekayu' society needs, but based on the field survey found that there are some consumers' dissatisfaction toward the product prices such as vegetables and meats at talang jawe traditional market Sekayu, from the front side to the vack side of the market, both have the same prices and expensive. Consumers are not allowed to bid because sellers think that how much the things will be sold, it will be bought by consumers. This condition which make the consumers feel dissatisfy to do transaction at Sekayu traditional market. Beside that, products offered in here have limited supply so the consumers found difficulty to buy in large quantities. Based on the writer' observation, the product prices at Sekayu traditional market is more expensive than others traditional markets in South Sumatera.

Results of interview authors to some consumers who are shopping at the market Talang Jawe Sekayu stated that the same price issue caused product distributor to include products in the Market Talang Jawe Sekayu not many. Therefore, the price of both vegetable and meat products the same price. In addition, every consumer who shop when making an offer to the average consumer merchant is only given a price that fits or with the traders' trademark especially in Talang Jawe Sekayu Market "nak payo ngan dem". It makes consumers feel dissatisfied with the attitude of traders.

The attitude of consumer dissatisfaction is expressed by some mothers who had writers met the market, they declared forced to buy because there is no other market as complete as traditional market Talang Jawe, there are also saying sometimes they prefer to choose to shop at the passing vegetables and bred sufficiently. If buying in bulk they prefer to buy to existing market in Palembang city or other area. Intnya they me, buy in Traditional Market Talang Jawe for the needs of little or just enough. Purchases in large numbers also become their disappointment because of the limited number of products available there.

Based on the phenomena have been stated, so the problems in this research are formulated as follows:

1. How the effect of product toward consumers' satisfaction at Sekayu traditional market?

2. How the effect of price toward consumers' satisfaction at Sekayu traditional market?

3. How the effect of product and price toward consumers' satisfaction at Sekayu traditional market?

\section{THEORY}

According to Tjiptono [1], product definition is everything that can be offered by the producer to be noticed, requested, searched for, bought, used and consumed by market as an effort to fulfill related market's needs and desires.

According to Kotler \& Keller [2], the indicators were used by the writer to measure the product in this research are: 

a. Kinds of sold products
b. Product suitability with price
c. Product quality

According to Kotler and Amstrong [3] some attributes that accompany and complement the product (product attribute characteristics) are:

a. Branding

Names, terms, signs, symbols, or designs, or any combination of these intended to identify products or services of one or a group of sellers and distinguish them from competing products.

b. Packing

Activity of designing and making container or wrapping of a product.

c. Product quality

Ability of a product to perform its functions include reliability, accuracy of ease of operation and improvement, and valuable attributes others.

According to Kotler and Amstrong [3], it's stated that price as amount of money which is billed on a product or service, or the sum of redeemed value by the consumers to get benefit of own or use a product or service. Indicators that characterize the price are:
a. Affordability
b. Price suitability with product quality
c. Price Competitiveness

According to Irawan [4], consumers' satisfaction is an accumulation result of consumers in using product and service. In this research consumers' satisfaction indicators are used according to Irawan [4], as follow:

a. Overall costumer satisfaction

b. Recommend to other parties

c. Reuse services

Kotler \& Amstrong [3] states that there are 4 elements in customer satisfaction are:

a. Expectation

The consumer's expectation of a good or service has been formed before the consumer purchases the goods or services. At the time of the purchase process, consumers expect that the goods or services they receive in accordance with their expectations, desires and beliefs. Goods or services in accordance with consumer expectations will cause consumers to be satisfied.

b. Performance

The consumer's experience of the actual performance of the goods or services when used without being influenced by their expectations. When the actual performance of goods or services is successful then the consumer will feel satisfied.

c. Comparison

This is done by comparing the expectations of the performance of goods or services before buying with perceptions of the actual performance of the goods or services. Consumers will be satisfied when expectations before purchase match or exceed their perception of the actual performance of the product.

d. Comfimation/discomfirmation

Consumer expectations are influenced by their experience of brand usage of goods or services that are different from others. Confirmation occurs when expectations match the actual performance of the product. otherwise disconfirmation occurs when expectations are higher or lower than the actual performance of the product. consumers will feel satisfied when the confirmation / discofirmation. 


\subsection{Related Previous Study}

The first research was conducted by Jahanshahi, e.t.al. [5] this research aimed to know the influence of service and product quality toward consumers' satisfaction and loyalty at outomotive industry in India. The research finding showed that there was big possitive influence between service quality and product quality toward consumers' satisfaction and loyalty, so there is link among product quality and its influence toward consumers' satisfaction.

The Second research was conducted by Nasir, et. al [6] which has goal to know the important factors those affect fast food restaurant consumers' satisfaction. Research finding be the basic consideration to research prices and understanding its influence toward consumers' satisfaction.

The third research was conducted by Lonardo and Soelasih [7] which has goal to analize the influence of product quality, price and physical environment toward "lapis legit" cake consumers' satisfaction. This research finding can be reference for this research to review price and quality product toward its influence with consumers' satisfaction.

The fourth research was conducted by Noto and Hakim [8] that did a research about analysis of the effect of product price and product quality toward consumers' satisfaction (Case study at Alin Motorbike Workshop services in Semarang). The result showed that the price variable and product quality have significantly and positively influence toward consumers' satisfaction so the hypothesis was accepted. This result showed that the consumers who satisfy with Alin Workshop motorbike Semarang with affordable and cheap product prices and good quality product.

The fofth research was conducted by Tristiana and Mashariono [9] which has goal to know the influence of product quality and price toward Honda Vario 125 motorbike consumers' satisfaction. Research findings showed that product quality variable, and price have significantly and positivelly effect toward consumers' satisfaction as Honda Vario 125 motorbike users at Dealer Panji Perkasa Perdana.

\section{METHODOLOGY}

Research method is a guideline for research about how a research steps are done. In this research, the writer use descriptive quantitative research method. According to Sugiyono [10], descriptive quantitative method is a research method that explain the relationship between variables and numeric data analysis by using statistical method through hypothesis testing.

According to Sanusi [11], the variables will be observed in this research those are independent variable $\left(\mathrm{X}_{1}\right),\left(\mathrm{X}_{2}\right)$ and dependent variable $(\mathrm{Y})$. More detail will be showed its operational as follow:

1. Independent variable, is a variable that affect another variable. In this research that will be independent variable is "Product and Price"

2. Dependent variable, is a variable that is affected by another variable. In this research that will be dependent variable is "Consumers' Satisfaction".

According to Sugiyono [10], population is all elements combination which has a series of similar characteristics, which include the universe for the sake of marketing research problems. Population in this research is all consumers who come to shop at Talang Jawe market in Sekayu. This technique was chosen because population and sample have certain characteristics. Those characteristics are: 
a. All consumers who come for shopping at traditional market especially Talang Jawe traditional market Sekayu.

b. Their ages are above 20 years old.

According to Hair, et al in Malhotra (2009: 369), if the population isn't known recommend the number of sample at least 5 times of the total question items in questionnaire. Indicators in this research are 12 question items of independent variables and 6 question items of dependent variables. The total of question in this research is 30 questions, so $18 \times 5=90$. So that, the total of sample was taken in this research is 90 respondent.

According to Malhotra [12], sample is the selected subgroup of population elements to participate in study. While the sampling technique in this research used non-probability sampling method (non random sampling) by sampling technique is purposive sampling, where the sample was chosen based on characyeristics.

In this research for sampling technique that is use Simple Random Sampling a technique for taking sample of a population which is done randomly regardless of the strata present in that population [10].

According to Sunyoto [13], to get the data and information neede by the writer, so the technique was used by the writer to collect the data in this research are:

a. Questionnaire

Questionnaire is a data collecting method that is done by giving questions to respondents with questionnaire guidelines. Questionnaire in this research used open and closed questions.

b. Interview

Interview is direct questionning with parties in a company to the appointed persons to interview in collecting data.

c. Documentation Study

Documentation study is a collecting data method that is done by reading books, literatures, journals, related references with this research and related previous studies those are related to the research is being done.

Research instruments will be used is a questionnaire that will be distribute to the consumers of Sekayu traditional market. By the measurement technique by using Likert scale and statistics of data processing by using SPSS For Windows Version 17.0 by the limitation as follow:

Very satisfy with score $=5$

Agree with score $\quad=4$

Confused with score $\quad=3$

Disagree with score $\quad=2$, and

Very disagree with score $=1$.

Likert scale is a scale that is used to measure attitude, opinion, and perception of someone/goup of people about social phenomena [10].

In this research, data analysis technique used Quantitative analysis technique. Quantitative analysis is an analysis method by using numbers those are able to calculated and measured. Quantitative analysis is intended to estimate the magnitude of influence by using statistic analysis tool. 
In analyzing statistic data used SPSS 17,0 (Statistical Product Service Solution), program that is an application program which has quite high capability of statistical analysis and data management system at geographic environment.

Validity Test, these testing are:

If : $\operatorname{sig} \mathrm{t}<\operatorname{sig} \alpha$, it means that those questions are valid

If : $\operatorname{sig} \mathrm{t}>\operatorname{sig} \alpha$, it means that those questions are invalid.

Reliability is used to measure a questionnaire that is an indicator of variable or construct. A questionnaire is said reliable if someone's answer is consistent and stable from time to time. SPSS gives the facility to measure reliability by Cronbach Alpha $(\alpha)$ statistic testing. A variable is said reliable if $(\alpha)$ value $>0,60$ [14].

This analysis is used to know the influence of quality product $\left(\mathrm{X}_{1}\right)$ and price $\left(\mathrm{X}_{2}\right)$ toward consumers' satisfaction (Y). According to Sunyoto [13], multiple linear regression equation is as follow:

Where :

$$
\mathbf{Y}=\mathbf{a}+\mathbf{b}_{1} \mathbf{X}_{1}+\mathbf{b}_{2} \mathbf{X} \mathbf{2}+\mathbf{e}
$$

$\mathrm{Y}=$ Consumers' satisfaction,

$\mathrm{a}=$ Constant

$\mathrm{b}_{1}, \mathrm{~b}_{2}=$ Regression Coefficient,

$\mathrm{X}_{1}=$ product,

$\mathrm{X}_{2}=$ Price and

$\mathrm{e}=$ error

a. Simultaneous Significance Test (F statistic Test)

In this test, $\mathrm{F}$ test is used to know the influence of significance level of independent variables simultaneously toward dependent variable [15], in this research, hyphotesis were used are:

$\mathrm{H}_{0}=$ There is no influence between product and price toward consumers' satisfaction at Sekayu traditional market.

$\mathrm{H}_{1}=$ There is influence between product and price toward consumers' satisfaction at Sekayu traditional market.

The Priyatno's basic decision making is by using significance probability numbers, those are:

1) If probability $\mathrm{H}_{\mathrm{O}}>\mathrm{H}_{\mathrm{a}}$, so there is no influence between product and price toward consumers' satisfaction at Sekayu traditional market.

2) If probability $\mathrm{H}_{\mathrm{O}}<\mathrm{H}_{\mathrm{a}}$, so there is influence between product and price toward consumers' satisfaction at Sekayu traditional market.

b. Test of partial significance influence $(\mathrm{T}-\mathrm{test})$

$\mathrm{T}$ test is used to test the significance relationship between $\mathrm{X}$ and $\mathrm{Y}$ variable, whether $\mathrm{X}_{1}$, $\mathrm{X}_{2}$ variables (product and price) really affect $\mathrm{Y}$ variable (consumers' variable), partially [15]. Hyphotesis were used in this testing are:

$\mathrm{H}_{0}=$ There is no influence betweeen product and price toward consumers' satisfaction at Sekayu traditional market.

$\mathrm{H}_{1}=$ There is influence between product and price toward consumers' satisfaction at Sekayu traditional market.

Prayitno's basic decision making (2009: 65) is by using number probability significance those are: 
1) If probability significance number $>0.05$, so $\mathrm{H}_{\mathrm{o}}$ was accepted and $\mathrm{H}_{\mathrm{a}}$ was rejected.

2) If probability significance number $<0.05$, so $\mathrm{H}_{\mathrm{o}}$ was rejected and $\mathrm{H}_{\mathrm{a}}$ was accepted

\section{RESULT AND DISCUSSION}

Validity test was used to know which questions can be used to simple linear regression. Based on questionnaire answers that the researcher got from 90 consumers of Sekayu traditional market which all of them are as sample of this research, found the result as follow:

a. From validity test result for the statement that relate to product was found that correlation value of all items/statements at the questionnaire have 2 side value at significance level $\leq$ 0.05 ( 2 tailed). So, it can be concluded that those items significantly correlate with the total score and it can be stated that those instruments are valid.

Table 1. Validity Test Result of $X_{1}$ variable

\begin{tabular}{ccccc}
\hline No & Item & Sig t & Sig $\boldsymbol{\alpha}$ & Ket. \\
\hline $\mathbf{1}$ & X1_1 & 0.00 & 0.05 & Valid \\
$\mathbf{2}$ & X1_2 & 0.00 & 0.05 & Valid \\
$\mathbf{3}$ & X1_3 & 0.00 & 0.05 & Valid \\
$\mathbf{4}$ & X1_4 & 0.00 & 0.05 & Valid \\
$\mathbf{5}$ & X1_5 & 0.00 & 0.05 & Valid \\
$\mathbf{6}$ & X1_6 & 0.00 & 0.05 & Valid \\
\hline
\end{tabular}

From validity test result for the statement that relate to price was found that correlation value of all items/statements at the questionnaire have 2 side value at significance level $\leq 0.05$ ( 2 tailed). So, it can be concluded that those items significantly correlate with the total score and it can be stated that those instruments are valid.

Table 2. Validity Test Result of $\mathrm{X}_{2}$ Variable

\begin{tabular}{ccccc}
\hline No & Item & Sig t & Sig $\boldsymbol{\alpha}$ & Ket. \\
\hline $\mathbf{1}$ & X2_1 & 0.00 & 0.05 & Valid \\
$\mathbf{2}$ & X2_2 & 0.00 & 0.05 & Valid \\
$\mathbf{3}$ & X2_3 & 0.00 & 0.05 & Valid \\
$\mathbf{4}$ & X2_4 & 0.00 & 0.05 & Valid \\
$\mathbf{5}$ & X2_5 & 0.00 & 0.05 & Valid \\
$\mathbf{6}$ & X2_6 & 0.00 & 0.05 & Valid \\
\hline
\end{tabular}

b. From validity test result for the statement that relate to consumers' satisfaction was found that correlation value of all items/statements at the questionnaire have 2 side value at significance level $\leq 0.05$ ( 2 tailed). So, it can be concluded that those items significantly correlate with the total score and it can be stated that those instruments are valid. 
Table 3. Validity Test Result of Y Variable

\begin{tabular}{ccccc}
\hline No & Item & Sig t & Sig $\boldsymbol{\alpha}$ & Ket. \\
\hline $\mathbf{1}$ & Y_1 & 0.00 & 0.05 & Valid \\
$\mathbf{2}$ & Y_2 & 0.00 & 0.05 & Valid \\
$\mathbf{3}$ & Y_3 & 0.00 & 0.05 & Valid \\
$\mathbf{4}$ & Y_4 & 0.00 & 0.05 & Valid \\
$\mathbf{5}$ & Y_5 & 0.00 & 0.05 & Valid \\
$\mathbf{6}$ & Y_6 & 0.00 & 0.05 & Valid \\
\hline
\end{tabular}

Based on those validity test results can be concluded that all statements at questionnaire amount 18 questions those are consist of statements relate to product, price and statements relate to consumers' satisfaction all three varaibles can be said passed of validity test.

Reliability test in this research was done to know whether product, price and consumers' satisfaction instruments are reliable or not. And the reliability test results of both instruments are:

a. From reliability result 6 statements those are relate to product were known that 6 statements are answered by 90 respondents Cronbach Alpha value was 0.709. Because of its value is higher than 0.6 , so it can be concluded that product instrument items can be said are reliable.

\begin{tabular}{|c|c|}
\hline Cronbach's Alpha & $\mathrm{N}$ of Items \\
\hline .709 & 6 \\
\hline
\end{tabular}

b. From reliability result 6 statements those are relate to product were known that 6 statements are answered by 90 respondents Cronbach Alpha value was 0.784 . Because of its value is higher than 0.6 , so it can be concluded that product instrument items can be said are reliable.

\begin{tabular}{rrr}
\hline Cronbach's Alpha & N of Items & \\
\hline .784 & & 6 \\
\hline
\end{tabular}

c. From reliability result 6 statements those are relate to product were known that 6 statements are answered by 90 respondents Cronbach Alpha 0.717 . Because of its value is higher than 0.6, so it can be concluded that product instrument items can be said are reliable.

\begin{tabular}{cc}
\hline Cronbach's Alpha & N of Items \\
\hline .717 & \\
\hline
\end{tabular}

Based on reliability test result for product, price, and consumers' satisfaction instrument can be concluded that the three instruments are reliable (passed of reliability test).

To define the multiple regression equation formula of product $\left(\mathrm{X}_{1}\right)$, and price $\left(\mathrm{X}_{2}\right)$ influence toward consumers' satisfaction $(\mathrm{Y})$ regression coefficient analysis needs to be done. By using SPSS program facility, regression analysis result can be seen as follow:

$$
\mathrm{Y}=8.73+0.522 \mathrm{X}_{1}+0160 \mathrm{X}_{2}
$$

While to see the magnitude of influence between variables need to be done coefficient and determination, can be seen at this table : 
Table 4. Correlation Coefficient and Determination

\begin{tabular}{llcrc}
\hline Model & $\mathrm{R}$ & $\begin{array}{c}\mathrm{R} \\
\text { Square }\end{array}$ & $\begin{array}{c}\text { Adjusted } \\
\mathrm{R} \text { Square }\end{array}$ & $\begin{array}{c}\text { Std. } \\
\text { Error of } \\
\text { the } \\
\text { Estimate }\end{array}$ \\
\hline 1 & $.627^{\mathrm{a}}$ & .393 & .379 & 2.185 \\
\hline
\end{tabular}

$\mathrm{T}$ test is a test to know independent variable influence significance (product and price) partially or individually explain the dependent variable (Consumers' satisfaction). T sig value at product variable $\left(\mathrm{X}_{1}\right)$ is 0.000 with sig $\alpha(0.05)$. Therefore t sig value $<\operatorname{sig} \alpha$ that is $0.000<$ 0.05 and at price variable $\left(\mathrm{X}_{2}\right)$ with significance level 0.041 . therefore $\mathrm{t}$ sig value $<\operatorname{sig} \alpha$ that is $0.041<0.05$, so $\mathrm{H}_{0}$ was rejected and $\mathrm{H}_{\mathrm{a}}$ was accepted, it means that there is significantly influence between product $\left(\mathrm{X}_{1}\right)$ and price $\left(\mathrm{X}_{2}\right)$ toward consumers' satisfaction.

Based on correlation coefficient and determination, showed that the magnitude of product variable influence $\left(\mathrm{X}_{1}\right)$ and price $\left(\mathrm{X}_{2}\right)$ toward consumers' satisfaction $(\mathrm{Y})$ was 0.393 (Adjusted $R$ Square), it means that the influence of product and price toward consumers' satisfaction at Sekayu traditional market showed there is positive correlation, which gives understanding that 39.3\% consumers' satisfaction variable (Y) is affected by price and product variables. And the rest about $60.7 \%$ can be explained or affected by other factors.

Simultaneously Hyphotesis testing aimed to measure the magnitude influence of independent variables simultaneously toward dependent variable. Based on calculation result table is obtained that the significance amount $000^{\mathrm{b}}$ by using significant level 0.05 so $\mathrm{F}$ significant value is amount 0.000 showed less than $0.05(0.000<0.05)$. therefore $\mathrm{H}_{\mathrm{a}}$ was accepted, so hyphoteses that said there is a significant influence between independent variable with price and product simultaneously toward dependent variable (Consumers' satisfaction).

\section{CONCLUSION}

1. Based on validity test analysis result $\mathrm{X}_{1}, \mathrm{X}_{2}$ and $\mathrm{Y}$ variables with correlation value of all items/statements at questionnaire has significant value less than 0.05 so the instrument are valid.

2. Reliability test result $X_{1}$ variable with Cronbach Alpha value is $0.709 X_{2}$ variable with Cronbach Alpha value is 0.784 and $\mathrm{Y}$ variable with Cronbach Alpha value is 0.717 with critical $r$ value ( 2 tailed test) at significant level 0.05 , so instrument items are reliable.

3. Based on analysis result of multiple linear regression is known that significance value at constant row is less than 0.05 that is amount 0.000 . it means that at $95 \%$ level of freedom. Ho was rejected and $\mathrm{Ha}$ was accepted and it means that product and price significantly affected toward consumers' satisfaction at Sekayu traditional market.

4. The result of multiple linear regression equation between product variable $\left(\mathrm{X}_{1}\right)$, price $\left(\mathrm{X}_{2}\right)$ toward consumers' satisfaction $(\mathrm{Y})$, is $\mathrm{Y}=8.73+0.522 \mathrm{X}_{1}+0160 \mathrm{X}_{2}$

5. Test result of correlation coefficient and determination showed that consumers' satisfaction variable (Y) is $39.3 \%$ affected by product and price variables. The rest $60.7 \%$ can be explained or affected by other variables. 


\section{References}

[1] F. Tjiptono and G. Chandra, Service, Quality \& Satisfaction, 3rd ed. Yogyakarta: Andi, 2010.

[2] P. Kotler and K. Keller, Manajemen Pemasaran. Jakarta: Erlangga, 2009.

[3] Kotler and Amstrong, Bauran Pemasaran dan Kepuasan Pelanggan. Bandung: Alfabeta, 2012.

[4] H. Irawan, Kepuasan Pelangggan. Jakarta: PT Gramedia Pustaka, 2008.

[5] A. A. Jahanshahi, M. A. H. Gashti, S. A. Mirdamadi, K. Nawaser, and S. M. S. Khaksar, "Studythe Effects of Customer Serviceand Product Quality on Customer Satisfaction and Loyalty,” Int. J. Humanit. Soc. Sci., vol. 1, no. 7, 2011.

[6] A. Nasir, M. A. Ahmed, I. Nazir, H. Zafar, and Z. Zahid, "Impact of Different Determinants on Customer's Satisfaction Level (A case of Fast Food Restaurant)," Int. J. Bus. Manag. Invent., vol. 3, no. 9, 2014.

[7] Lonardo and Y. Soelasih, “Analisis Pengaruh Kualitas Produk, Harga, dan Lingkungan Fisik Perusahaan Kue Lapis Legit XYZ terhadap Kepuasan Konsumen dalam Membangun Word of Mouth Positif," J. Manaj., vol. 11, no. 1, 2014.

[8] E. H. Noto and L. Hakim, “ANALISIS PENGARUH HARGA PRODUK DAN KUALITAS PRODUK TERHADAP KEPUASAN PELANGGAN (Studi Kasus Jasa bengkel Alin Motor Semarang)," J. Ilm. Among Makarti, vol. 9, no. 17, 2016.

[9] A. Tristiana and Mashariono, "Pengaruh Kualitas Produk Dan Harga Terhadap Kepuasan Konsumen Sepeda Motor Honda Vario 125,” J. Ilmu dan Ris. Manaj., vol. 5, no. 6, 2016.

[10] Sugiyono, Metode Penelitian Manajemen. Bandung: Alfabeta, 2009.

[11] S. Anwar, Metodologi Penelitian Bisnis. Jakarta: Salemba Empat, 2011.

[12] N. K. Malhotra, Riset Pemasaran. Jakarta: PT Indeks, 2009.

[13] D. Sunyoto, Metodologi Penelitian Akuntansi. Bandung: Refika Aditama, 2013.

[14] I. Ghozali, Aplikasi Analisis Multivariate dengan Program SPSS. Semarang: Badan Penerbit Universitas Diponegoro, 2009.

[15] P. Duwi, SPSS Untuk Analisis Korelasi, Regresi, dan Multivariate. Yogyakarta: Penerbit Gava Media, 2009. 